\title{
Biocidal potential of Three Plant Extracts on Rhizopus stolonifer, Causal Organism of Irish Potato (Solanum tuberosum L.) Tuber Rot
}

\author{
Chuku, E.C, ${ }^{*}$ Njoku, A.A. and Nmom, F.W. \\ Department of Plant Science \& Biotechnology, Rivers State University, \\ Nkpolu-Oroworukwo, Port Harcourt, Nigeria.
}

\begin{abstract}
Research study was carried out to assess the biocidal effect of aqueous extracts of Curcuma longa, Zingiber officinale, Citrus limon peel and synthetic fungicide Mancozeb against Rhizopus stolonifer using the poisoned food technique on PDA. Various concentrations $(50,75$, and $100 \%)$ of extracts from the rhizomes of $C$. longa, $Z$. officinale, the peel of $C$. limon and Mancozeb $(0.002 \%)$ significantly inhibited the mycelia growth of $\boldsymbol{R}$. stolonifer after 3 days. Effects of the synthetic fungicide (Mancozeb) comparative to the plant extracts were also determined. Although the extracts showed varying degrees of antifungal efficacy, $100 \%$ concentration of $Z$. officinale $(58.96 \%)$ proved to be more potent against $R$. stolonifer than the other plant extracts but was lower and significantly different when compared with Mancozeb $(\mathbf{7 3 . 3 1 \%})$ at $(P \leq 0.05)$ after 3 days. Extracts of $C$. longa and $C$. limon peel showed a lower inhibition level ranging from $45.01 \%$ to $56.98 \%$ and $9.57 \%$ to $18.73 \%$ respectively and were significantly different when compared with Mancozeb at $(\mathbf{P} \leq \mathbf{0 . 0 5})$. Inhibition of fungal growth increased with a corresponding increase in extract concentration and days. The plant leaf extracts effectively inhibited the mycelial growth of pathogen in vitro after 3 days. In vivo study was carried out using spore suspensions of $R$. stolonifer. Fresh, healthy and surface sterilized Irish potato tubers were inoculated with $6.4 \times 10^{4}$ spores $/ \mathrm{ml}$ and treated with aqueous extracts of $C$. longa, $Z$. officinale and $C$. limon peel after 24 hours. The result showed that all plant extracts had significant effect on disease severity in tubers inoculated with $R$. stolonifer. However, $100 \%$ concentration of $Z$. officinale gave the best rot reduction caused by $R$. stolonifer with severity score of 0.33 but it was not significantly different at $(p<0.05)$ from mancozeb which had a severity score of 0.67. However, they were significantly different at $(\mathbf{p}<0.05)$ from the inoculated control (3.33). There were variations in weight loss but no significant difference was observed among the various treatment methods adopted.
\end{abstract}

Keywords:- Biocides, plant extracts, Rhizopus stolonifer, Irish potato Tuber Rot.

\section{INTRODUCTION}

Irish Potato (Solanum tuberosum L.) is an annual swollen underground stem tuber crop belonging to the family Solanaceae. It is an important tuber crop ranked fourth most important crop in the world (Ugonna et al., 2013; FAO, 2014). Since introduction, the production of potato has increased by over $120 \%$ in the past decade in Nigeria and it is still grossly below demand (FAO, 2014). Despite Nigeria being the highest producer of potato in Africa and second highest in the world, Nigeria is not an exporter of potato (ITC, 2016). This has been attributed to various constraints. According to Ugonna et al. (2013), some constraints which limit Irish potato production, processing and marketing in Nigeria include Poor diseases and pests' management, inadequate storage facilities and inadequate supply of good quality seeds

Chukwu et al., (2008) stated that the availability of tuber crops has been limited because of the unavailability of good storage facilities and techniques. High percentage losses have been reported due to the in-effectiveness of traditional storage techniques such as pit storage and barnheaping of the tubers. Losses between $40-60 \%$ have been attributed to poor storage methods and pathogens like Mucor racemosus., Alterneria alternata., Rhizopus stolonifer, Phythophthora infestans, Pythium myriothylium, Botryodiplodia theobromae, Fusarium solani and Fusarium oxysporum (Chuku et al., 2005; Ubalua and Chukwu, 2008). The effect of these losses can be translated to mean a decrease in revenue and threat to reliance on the crop as a major staple carbohydrate food crop in this present economic situation.

The use of chemicals have aided in the management of diseases but numerous problems such as, nonbiodegradation, high cost, chemical residue retention in the plant produce, development of resistance in target organism, phytotoxicity, hazard to man and his environment and sometimes non-availability have rendered chemicals either difficult to adopt or farmers to have rejected them, in addition to various cultural and religious reasons (Abimbola et al., 1993; Okigbo and Odurukwe, 2009). Hence, there is a pressing need to find alternatives to these existing methods with lesser or no side effects, readily available and less expensive (Khulbe and Sati, 2009). 
In many parts of the world, scientists have discovered the many possibilities in using plants and their extracts for treating plant diseases (Sofowora, 1984; Okigbo and Igwe, 2007). These higher plants have shown amazing potency as sources for new drugs although it is still largely under utilized. (Ahmedulla and Nayar, 1994). These plants derivatives are being used in several forms such as; liquid, powder, mixtures, spice, ointments, etc., (Apata, 1979; Wee yeow Chin, 1992). Plant-based products are generally affordable, readily available, non-phytotoxic and easily biodegradable. Moreover, they are ecofriendly and stand as alternative to chemical fungicides as reported by different scholars (Akhilesh et al., 2012; Okigbo and Omodamiro, 2006 and Okigbo and Igwe 2007). This study was aimed at evaluating the biocidal potentials of aqueous extracts of Curcuma longa, Zingiber officinale, Citrus limon peel against Rhizopus stolonifer, the causal organism of Irish potato tuber rot.

\section{$>$ Sample Collection}

Irish potato (Solanum tuberosum) tubers with rot symptoms were procured from Rumuokoro market in Obio -Akpor Local Government Area, Rivers State, South-South Nigeria. Fresh and apparently healthy tubers were procured from the same market. Rhizomes of Ginger (Zingiber officinale), Turmeric (Curcuma longa) and fruits of Lemon (Citrus limon) were procured from the Fruit Garden Market in D/line area of Port Harcourt, Rivers State. Synthetic fungicide (Mancozeb) was obtained from Agricultural Development Programme unit (Rivers ADP) of the Rivers State Government.

\section{$>$ Isolation of Fungal Pathogens from Irish Potato Tubers}

Infected potato tubers were surface sterilized in 5\% Sodium hypochlorite and then rinsed thrice in sterile distilled water (SDW) according to the method of (Ritchie, 1991). Approximately $2 \mathrm{~mm}$ cubes were cut from the tissue at the junction between healthy and infected portion of potato tubers using a sterilized scalpel. These sections were inoculated to Petri dishes containing sterilized Potato Dextrose Agar (PDA) and incubated at $28 \pm 2^{\circ} \mathrm{C}$ for 7 days and then examined for the development of fungi growth.

\section{> Subculturing, Purification and Identification of Test Fungi Pathogens.}

When growth was established, subcultures were prepared using inocula from the different fungi in the mixed cultures in order to obtain pure culture. This was done by transferring the hyphal tips from the colony edge of the mixed cultures to fresh plates of Potato Dextrose Agar using flame sterilized inoculating needle. After subculturing, the plates were incubated at $28 \pm 2^{0} \mathrm{C}$ for 7 days. The process was repeatedly done until pure cultures were obtained. The resulting pure cultures were used for characterization and subsequent identification of the fungal isolates based on their characteristics, using identification guides by (Barnett and Hunter, 2008). Stock cultures were maintained on agar slants in McCartney bottles and stored at $4{ }^{0} \mathrm{C}$ in the refrigerator.

\section{$>$ Pathogenicity Test}

Pathogenicity test was carried out according to the methods described by Chuku et al, (2005) and Nwachukwu and Osuji (2008). A mycelia disk (5mm) of the test fungus (Rhizopus stolonifer) from pure culture was cultured for 14 days in a sterilized Potato Dextrose Agar (PDA) broth containing $1 \mathrm{~g}$ of PDA mixed in $140 \mathrm{ml}$ Sterile Distilled Water. The culture was filtered using No 1 Whatman filter paper and transferred into a $50 \mathrm{ml}$ distilled water containing $10 \%$ glucose.

The mixture was properly agitated and sprayed on fresh surfaced sterile uninfected potato tubers. The tubers were kept at room temperature $\left(28 \pm 2^{\circ} \mathrm{C}\right)$ for 14 days to examine for symptoms of rot and thus prove that the test fungi were able to cause infection.

\section{Preparation of Stock Solution of the Plant Extracts}

15 grams of each plant powder was mixed in $100 \mathrm{ml}$ of Sterile Distilled Water, stirred vigorously and kept for 24 hours in other to obtain a stock solution. The extracts was decanted, filtered through a No. 1 Whatman filter paper and stored in a refrigerator at $4^{\circ} \mathrm{C}$ and used within 48 hours. The stock solution of the plant extracts were diluted to $50 \%$, $75 \%$ and $100 \%$ concentration respectively. 50\% was got by diluting $50 \mathrm{ml}$ of the stock solution to $50 \mathrm{ml}$ of distilled water; $75 \%$ was obtained by diluting $75 \mathrm{ml}$ of stock solution in $25 \mathrm{ml}$ of distilled water; whilst $100 \%$ was $100 \mathrm{ml}$ of stock solution only and was used in the in vitro experiment.

\section{$>$ In vitro Bioassay: Effect of Plant Extracts and Mancozeb on Diametric growth of the Pathogen- Rhizopus stolonifer}

Thirty nine $(39 \mathrm{~g})$ of PDA powder was dispensed into $1000 \mathrm{ml}$ of sterile distilled water in a conical flask and the mouth was covered with non-absorbent cotton wool and aluminum foil. This was autoclaved at a temperature of $121^{\circ} \mathrm{C}$ and pressure of $15 \mathrm{~atm}$ for 15 minutes. About $2 \mathrm{ml}$ of the different concentration of the plant extracts was mixed with $10 \mathrm{ml}$ PDA and dispensed into the Petri dish, the medium was uniformly mixed and allowed to cool and solidify. For positive control, $2 \mathrm{ml}$ of $0.002 \%$ of fungicide (Mancozeb), obtained by diluting $2 \mathrm{gms}$ of fungicide in $1000 \mathrm{ml}$ of distilled water was mixed with $10 \mathrm{ml}$ PDA poured into Petri dish and allowed to solidify.

Two intersecting lines were drawn at the bottom of the petri dish to determine the centre of the plate. A disc $(5 \mathrm{~mm}$ diameter) of a 3 - 4 day old culture of the fungal pathogen (Rhizopus stolonifer) was placed at the centre of each plate amended with various concentrations of plant extracts and fungicide respectively. The Completely Randomized Designed experiment had 3 replications per treatment. The control experiment had no plant extract treatment. Inoculated plates were incubated at temperature of $28 \pm 2^{\circ} \mathrm{C}$. The diameter of the growth of the test fungi was measured daily for three days and then used to detect the fungal toxicity levels of the extracts using the formula according to Chuku et al. (2005). 
$\%$ growth inhibition $=($ DC-DT $) /($ DC $) \times 100 / 1$ Where $D C=$ is the farthest diametric distance of pathogen in control plate

DT $=$ is the farthest diametric distance of pathogen colony in extract incorporated plates

\section{$>$ In vivo Test Using Plant Extracts.}

This was carried out according to the methods of Nwauzoma et al., (2017). About three 5mm mycelia disk of the pathogen ( $R$. stolonifer) from a 4 days old pure culture was grown for 14days in a PDA broth containing $1 \mathrm{~g}$ of PDA mixed in $200 \mathrm{ml}$ sterile distilled water. The culture was filtered using No. 1 Whatman filter paper and transferred into $300 \mathrm{ml}$ distilled water containing $10 \%$ glucose. The mixtures were properly agitated and $6.4 \times 10^{4}$ (spores $/ \mathrm{ml}$ ) suspension was obtained using a haemocytometer. This was sprayed separately on fresh surface sterile uninfected Irish potato at $10 \mathrm{ml}$ per tuber. Plant extracts at various concentrations of $50 \%, 75 \%$ and $100 \%$ was sprayed on the tubers 24 hours later, using a sterile manual hand spray pump. $10 \mathrm{ml}$ of $0.002 \%$ Mancozeb, (fungicide) was applied as positive control. Also, inoculated and un-inoculated controls were kept. The
Completely Randomized Design experiment was replicated thrice. The infected tubers were kept for 5 weeks at a temperature of $28 \pm 2^{0} \mathrm{C}$ in order to access the disease severity.

The severity of the infection after 5 weeks was assessed by visual observation and scoring was done according to Nwachukwu and Osuji (2008) based on a $0-4$ scale.

0 -no infection

1-slight infection

2-moderate infection (50\% of tuber infected.)

3 -severe infection ( $75 \%$ of tuber infected)

4-complete rot (100\% infection).

Also, Weight loss was observed weekly for five (5) weeks and percentage weight loss was calculated using the formula,

$\%$ Weight loss $=($ IW-FW/IW $) \times 100 / 1$

IW= Weight before inoculation

FW = Final weight after 7, 14, 21, 28 and 35days

\section{RESULT}

\begin{tabular}{|c|c|c|c|}
\hline \multirow[t]{2}{*}{ Treatments } & \multicolumn{3}{|c|}{ Percentage Inhibition (\%) } \\
\hline & Day 1 & Day 2 & Day 3 \\
\hline Control & $0.00^{\mathrm{a}}$ & $0.0000^{\mathrm{a}}$ & $0.00^{\mathrm{a}}$ \\
\hline Mancozeb & $66.23^{\mathrm{h}}$ & $69.99^{\mathrm{j}}$ & $73.31^{\mathrm{i}}$ \\
\hline Z. officinale $50 \%$ & $22.46^{\mathrm{c}}$ & $39.41^{\mathrm{e}}$ & $45.01^{\mathrm{e}}$ \\
\hline Z. officinale $\mathbf{7 5 \%}$ & $29.96^{\mathrm{de}}$ & $42.35^{\mathrm{f}}$ & $47.81^{\mathrm{f}}$ \\
\hline Z. officinale $100 \%$ & $38.67^{\mathrm{f}}$ & $47.07^{\mathrm{h}}$ & $58.96^{\mathrm{h}}$ \\
\hline C. limon Peel $50 \%$ & $13.77^{\mathrm{b}}$ & $7.05^{\mathrm{b}}$ & $9.57^{\mathrm{b}}$ \\
\hline C. limon Peel 75\% & $19.99^{c}$ & $11.76^{\mathrm{c}}$ & $14.35^{\mathrm{c}}$ \\
\hline C. limon Peel $100 \%$ & $27.49^{\mathrm{d}}$ & $16.47^{\mathrm{d}}$ & $18.73^{\mathrm{d}}$ \\
\hline C. longa $50 \%$ & $27.49^{\mathrm{d}}$ & $44.71^{\mathrm{g}}$ & $45.013^{\mathrm{e}}$ \\
\hline C. longa $75 \%$ & $33.71^{\mathrm{e}}$ & $48.24^{\mathrm{h}}$ & $48.21^{\mathrm{f}}$ \\
\hline C. longa $100 \%$ & $44.97^{\mathrm{g}}$ & $51.17^{\mathrm{i}}$ & $56.98^{\mathrm{g}}$ \\
\hline
\end{tabular}

N.B. Means within the same column with different super script $\left({ }^{\mathrm{a}, \mathrm{b}, \mathrm{c}, \mathrm{d}}\right)$ are significantly different $(\mathrm{P}<0.05)$ according to DMRT

Table 1:- Effect of Plant Extracts and Mancozeb on Diametric Growth of $R$. stolonifer after 3 Days

The effect of plant extracts on diametric growth of the pathogen after 24 hours is presented in table 1. Mancozeb as well as the plant extracts inhibited the growth of $R$. stolonifer by $66.23 \%$. However it was significantly different at $(\mathrm{p}<0.05)$ from the plant extracts. Among the extracts, $100 \%$ concentration of $C$. longa recorded a percentage inhibition of $44.97 \%$ and it was significantly different at $(\mathrm{P}<0.05)$ from $100 \%$ concentrations of $C$. limon peel and Z. officinale with percentage inhibition of $27.49 \%$ and $38.67 \%$ respectively after 24 hours. Also, Mancozeb had the highest percentage inhibition of the growth of $R$. stolonifer with a percentage inhibition of 69.99 after 48 hours. However it was significantly different $(\mathrm{p}<0.05)$ from the plant extracts. Among the extracts, $100 \%$ concentration of C. longa recorded a percentage inhibition of $51.17 \%$ and it was significantly different $(\mathrm{P}<0.05)$ from $100 \%$ concentrations of $C$. limon peel and $Z$. officinale with inhibition percentage of $16.47 \%$ and $47.07 \%$ respectively. The $100 \%$ concentration of $C$. limon peel $(18.73 \%)$ had the lowest percentage inhibition among the plant extracts and was statistically different $(\mathrm{p}<0.05)$ from $100 \%$ concentration $Z$. officinale with a percentage inhibition of $58.96 \%$ after 3 days. The percentage inhibition of $100 \%$ concentration of $Z$. officinale $(58.96 \%)$ was higher than and statistically different $(\mathrm{p}<0.05)$ from other plant extracts but was lower and statistically different $(\mathrm{p}<0.05)$ from Mancozeb (73.31\%) after 3 days.

Table 2 shows disease development and severity under each treatment method adopted after 5 weeks. The rate of rot caused by Rhizopus stolonifer was reduced by the botanicals and mancozeb at each treatment method used. The $100 \%$ concentrations of $Z$. officinale gave the best rot reduction caused by $R$. stolonifer with severity 
score of 0.33 but it was not significantly different $(\mathrm{p}<0.05)$ from $100 \%$ concentration of $C$. longa, $C$. limon peel and mancozeb with severity scores of $0.67,1.33$ and 0.67 respectively. However, they were better and significantly different $(\mathrm{p}<0.05)$ from the inoculate control with a score of 3.33 .

\begin{tabular}{|c|c|}
\hline Treatments & Rot Development $^{\mid}$ \\
\hline Z. officinale 50\% & $3 \pm 0^{\mathrm{c}}$ \\
\hline Z. officinale 75\% & $0.33 \pm 0.58^{\mathrm{a}}$ \\
\hline Z. officinale 100\% & $0.33 \pm 0.58^{\mathrm{a}}$ \\
\hline C. limon Peel 50\% & $1.67 \pm 0.58^{\mathrm{b}}$ \\
\hline C. limon Peel 75\% & $1.33 \pm 0.58^{\mathrm{ab}}$ \\
\hline C. limon Peel 100\% & $1.33 \pm 0.58^{\mathrm{ab}}$ \\
\hline C. longa 50\% & $1.67 \pm 1.15^{\mathrm{b}}$ \\
\hline C. longa 75\% & $1.33 \pm 0.58^{\mathrm{ab}}$ \\
\hline C. longa 100\% & $0.67 \pm 0.58^{\mathrm{ab}}$ \\
\hline Mancozeb & $0.67 \pm 0.58^{\mathrm{ab}}$ \\
\hline Inoculated control & $3.33 \pm 0.58^{\mathrm{c}}$ \\
\hline Uninoculated control & $0.67 \pm 0.58^{\mathrm{ab}}$ \\
\hline Significant Difference & $<.0001^{*}$ \\
\hline
\end{tabular}

N.B. Means within the same column with different super script $\left({ }^{\mathrm{a}, \mathrm{b}, \mathrm{c}, \mathrm{d}}\right)$ are significantly different $(\mathrm{P}<0.05)$ according to DMRT.

Table 2:- Effects of Plant Extracts and Mancozeb on Rot Development after 5 Weeks Incubation

Table 3 shows the percentage weight loss in Irish potato tubers inoculated with $R$. stolonifer recorded weekly for 5 weeks. The $75 \%$ concentration of $C$. limon peel recorded the highest percentage weight loss $9.65 \%, 12.73 \%, 16.39 \%$ for weeks 1,2 and 3 respectively while inoculated control $19.12 \%$ and $25.44 \%$ had the highest percentage weight loss for week 4 and 5 respectively. $C$. longa at $100 \%$ concentration had a percentage weight loss of $4.64 \%, 6.25 \%, 8.64 \%, 9.47 \%$ and $10.51 \%$ in week $1,2,3,4$ and 5 respectively. Mancozeb had a percentage weight loss of $6.4 \%, 8.5 \%, 12 \%, 13.03 \%$ and $13.93 \%$ in week 1, 2, 3, 4 and 5 respectively. There was no statistical difference $(\mathrm{P} \leq 0.05)$ in percentage weight loss in all treatments and all weeks.

\begin{tabular}{|c|c|c|c|c|c|}
\hline \multirow{2}{*}{ Treatment } & \multirow[b]{2}{*}{ Week 1} & \multirow[b]{2}{*}{ Week 2} & \multirow[b]{2}{*}{ Week 3} & \multirow[b]{2}{*}{ Week 4} & \multirow[b]{2}{*}{ Week 5} \\
\hline & & & & & \\
\hline Z. officinale_50 & $4.72 \pm 3.58$ & $7.07 \pm 5.66$ & $11.55 \pm 10.57$ & $13.35 \pm 12.87$ & $15.57 \pm 15.77$ \\
\hline Z. officinale_75 & $2.08 \pm 0.43$ & $3.08 \pm 0.43$ & $4.84 \pm 0.51$ & $5.33 \pm 0.59$ & $5.87 \pm 0.62$ \\
\hline Z. officinale_100 & $5.54 \pm 5.22$ & $7.44 \pm 6.91$ & $10.85 \pm 9.82$ & $11.87 \pm 10.93$ & $13.11 \pm 12.03$ \\
\hline C. limon Peel_50 & $4.53 \pm 3.21$ & $5.68 \pm 3.63$ & $7.63 \pm 4.01$ & $9.57 \pm 4.76$ & $8.54 \pm 4.22$ \\
\hline C. limon Peel_75 & $9.65 \pm 7.9$ & $12.73 \pm 10.57$ & $16.39 \pm 12.67$ & $18.88 \pm 15.84$ & $21.54 \pm 19.19$ \\
\hline C. limon Peel_100 & $3.73 \pm 2.01$ & $5.19 \pm 2.59$ & $7.57 \pm 3.29$ & $8.16 \pm 3.54$ & $8.76 \pm 3.8$ \\
\hline C. longa_50 & $6.02 \pm 4.06$ & $7.91 \pm 5.13$ & $11.71 \pm 8.13$ & $17.39 \pm 16.39$ & $24.58 \pm 27.48$ \\
\hline C. longa_75 & $4.97 \pm 2.95$ & $6.72 \pm 3.68$ & $10.13 \pm 5.32$ & $13.55 \pm 5.84$ & $16.39 \pm 8.48$ \\
\hline C. longa_100 & $4.64 \pm 3$ & $6.25 \pm 3.75$ & $8.64 \pm 4.9$ & $9.47 \pm 5.38$ & $10.51 \pm 5.94$ \\
\hline Mancozeb & $6.4 \pm 4.07$ & $8.5 \pm 5.65$ & $12 \pm 8.21$ & $13.03 \pm 9.21$ & $13.93 \pm 10.27$ \\
\hline Inoculated control & $4.04 \pm 0.59$ & $6.02 \pm 0.5$ & $10.05 \pm 3.26$ & $19.12 \pm 17.66$ & $25.44 \pm 28.07$ \\
\hline Uninoculated control & $5.41 \pm 5.17$ & $7.44 \pm 6.64$ & $11.22 \pm 8.83$ & $12.6 \pm 9.68$ & $13.63 \pm 10.64$ \\
\hline P Value & 0.8019 & 0.8428 & 0.9169 & 0.9063 & 0.8592 \\
\hline Significant Difference & $\mathrm{NO}$ & NO & $\mathrm{NO}$ & NO & $\mathrm{NO}$ \\
\hline
\end{tabular}

Table 3:- Effects of Plant Extracts and Mancozeb on Weight of $R$. stolonifer Inoculated Tubers after 5 Weeks Incubation

\section{DISCUSSION}

Rhizopus stolonifer is an important fungal pathogen of Irish potato in Nigeria. It has been reported to cause extensive rot of Irish potato tubers in storage (Clark and Hoy 1994; Onuegbu, 2002; Muhammed et al., 2004; Oyewale, 2006; Ameinyo and Ataga, 2006; Salami and
Popoola, 2007; Mohammed et. al., 2017). Tuber losses of up to $25 \%$ has been attributed to this organism (Owunbiko and Mbanaso, 2005).

The inhibition of $R$. stolonifer by extracts of $\mathrm{Z}$. officinale, $C$. longa and $C$. limon peel may be attributed to the presence of antimicrobial substances, tannins, 
flavonoids and saponin found in the extract. This result is in agreement with the findings of Giriraju and Yumus (2013), who reported that $Z$. officinale extracts showed antimicrobial activities against some plant pathogens. Also, various studies of $\mathrm{Z}$. officinale showed that gingerol an important root extract of the plant, and shagaols, the dehydrated form of gingerols significantly inhibited the growth of some fungal and bacteria pathogens (Mahady et al., 2003; Azu and Onyeagba, 2007; Chen et al., 2008, Ali et al 2008; Jiang et al 2006). In same way, extracts of $C$. longa have shown antimicrobial activity against molds and bacteria such as Aspergillus niger, Penicillium digitatum, Aspergillus flavus, Penicillium javanium, Curvularia oryzae, Trichophyton mentagrophytes, Escherichia coli, Staphylococcus aureus, Salmonella typhi and Candida albicans and have been reported by earlier workers (Kapoor 1997; Arora and Kaur 1999, Gal and Bakht, 2015). Citrus plants have been reported to display a wide spectrum of antibacterial and antifungal activity against microorganisms such as Fusarium oxysporium, Penicillium chrysogenum, Aspergillus niger, Trichophyton rubrum and Candida albicans (Akhilesh et al., 2012; Junab et al., 2017).

The in vivo study revealed the effects of the plant extracts on rot development and weight loss in Irish potato tubers inoculated with $R$. stolonifer. The extract of the test plants reduced tuber rot of Irish potato when applied 24 hours after inoculation with $R$. stolonifer. There was no statistical difference $(\mathrm{p}<0.05)$ when compared with synthetic fungicide (mancozeb) and uninoculated control respectively. This result indicates that the extracts of the test plants could effectively reduce rot development in Irish potato tubers at test concentrations. The ability of plant extracts to reduce rot in tuber crops have been reported by earlier researchers (Nwachukwu and Osuji, 2008; Strivastava and Kshma, 2014: Boungab et al. 2015; Nwauzoma et. al., 2017). Also, Plant extracts have been reported to reduce weight loss in tubers. Eze et. al. (2015) reported that Cassia alata reduced weight loss and rot in cocoyam cormels in Enugu State, Nigeria. Similar results on the reduction of weight loss using ashes from the bark of kola nut tree, neem tree, and inflorescence of oil palm have been reported (Eze, 1991). In a related study, Nwauzoma et al. (2017) reported that leaf extracts of Carica papaya, Chromolaena odorata and Azadirachta indica significantly reduced rot in Sclerotium rolfsii inoculated tubers after 14 days in storage.

\section{CONCLUSION}

The inhibitory effects of extracts on growth of pathogen in vitro and in vivo varied with concentration of the plant extract. Increase in concentration and days had a corresponding increase in percentage inhibition of growth of the pathogen in vitro. This is not unconnected with the increase in the amount of phytochemical constituents.

\section{RECOMMENDATION}

It is recommended that the use of extracts of $\mathrm{Z}$. officinale, C. longa and C. limon peel should be encouraged as part of an integrated approach for the control of Irish potato tuber rot caused by $R$. stolonifer. It is also recommended that further investigations should be done on the chemical nature of the active principles of the plants; further investigations can combine the plant extracts for possible synergistic effect.

\section{REFERENCES}

[1]. Abimbola, K. A., Obi, C. L., Alabi, S. A., Olukoya, D. K. and Ndip, R. N. (1993). Current Status on biotyping antibiogram and plasmid profiles of $E$. coli isolates. East Afr. Med. J., 70:207-210.

[2]. Akhilesh, K., Raghvendra, P., Vikas, S.and Madhulika, G. (2012). Antimicrobial property of lemon peel extract. Natl J Universal Pharm Life Sci;52:382-6.

[3]. Ali, B. H., Blunden, G., Tanira, M. O., Nemmar, A. (2008). Some Phytochemical, Pharmacological and toxicological properties of ginger (Zingiber officinale Roscoe): A review of recent research. Food chemistry Toxicology 46(2): 409-420.

[4]. Amienyo, C.A. and Ataga, A. E. 2007. Use of indigenous plant extracts for the protection of mechanically injured sweet potato (Ipomea batatas (L.) Lam) tuber. Scientific Research and Essay, 2 (5): 167-170.

[5]. Apata, L. (1979). Practice of Herbalism in Nigeria. University of Ife Press.

[6]. Arora, D. S. and Kaur, J. (1999). Antimicrobial activity of spices. Intl Journal of Antimicrobial Agents, 12:257-262.

[7]. Azu, N. and Onyeagba, R. (2007). Antimicrobial Properties of Extracts of Allium cepa (Onions) and Zingiber officinale (Ginger) On Escherichia coli, Salmonella typhi and Bacillus subtilis. Journal of Tropical Medicine, 3:1-10.

[8]. Barnett, H. H. \& Hunter, B. B. (2008) Illustrated genera of Imperfect fungi. Minnesota. USA: Burgess

[9]. Boungab, K., Tadjeddine, A., Belabid, L., Fortas, Z. \& Bassam B. (2015). Exploitation of some plant extracts for ecofriendly management of Net Blotch of Barley. Journal of Chemical and Pharmaceutical Research, 7(2), 732-739

[10]. Chen, I. N., Chang, C. C., Ng, C. C., Wang, C. Y., Shyu, Y. T. and Chang, T. L. (2008). Antioxidant and Antimicrobial Activity of Zingiberaceous Plants in Taiwan. Plants Foods Hum. Nutr. 63:15-20.

[11]. Chuku, E.C., Achinewhu, S. C., and Adeleke, M. T. V., (2005). Varietal effects on mould growth and storage duration of sweet potato (Ipomea batatas L) and Irish Potato (Solanum tuberosum L) Journal of Scientific and industrial studies 3 (4), 85 -63. 
[12]. Chukwu, G. O., Nwosu, K. I., Onyeke, J. \& Asiedu, R. (2008). Cocoyam rebirth in Nigeria, Paper presented at the 1st International Workshop on Cocoyam, IRAD, Ekonna, Cameroon, 29-31 October, 2008.

[13]. Clark, C. A. and Hoy, M. W. (1994). Identification of resistances in sweet potato to $\mathrm{R}$. stolonifer soft rot using two inoculation methods. Plant Disease 78(11): $1078-1081$

[14]. Eze, C. S. (1991). Studies on Microbial Rotting of Cocoyam (Colocasia esculenta L.) in Storage at Nsukka. Ph.D. Thesis, Nigeria: Department of Botany, University of Nigeria, Nsukka, Enugu, Nigeria.

[15]. FAOSTAT (2014). Food and Agricultural Organization of the United Nations. Production Statistics.

[16]. Giriraju, A. and Yunus, G. Y. (2013). Assessment of antimicrobial potential of $10 \%$ ginger extract against Streptococcus mutans, Candida albicans, and Enterococcus faecalis: an in vitro study. Indian J Dent Res., 24:397-400.

[17]. Gul, P. and Bakht, J. (2015). Antimicrobial activity of turmeric extract and its potential use in food industry. Journal of food science and technology, 52(4): 22722279.

[18]. International Trade Centre (ITC) Trade Competitiveness Map, http://www.trademap.org; UN COMTRADE

[19]. Jiang, H., Xie, Z., Koo, H. J., Mclaughlin, S. P., Timmermann, B. N. (2006). Metabolic Profilling and Phylogenetic analysis of medicinal Zingiber species: Tools for authentication of ginger (Zingiber officinale Roscoe). Phytochemistry 67 (15):1673-1685.

[20]. Junab, A., Biswajit, D. and Trideep, S. (2017). Antimicrobial Activity of Lemon Peel (Citrus Limon) Extract. International Journal of Current Pharmaceutical Research 9(4):79-82.

[21]. Kapoor, A. (1997). Antifungal activity of fresh juice and aqueous extracts of turmeric and ginger (Zingiber officinale). J Phytol Res., 10:59.

[22]. Khulbe, K. and Sati, S. C. (2009). Antibacterial Activity of Boenning hauseniaalbi flora Reichb (Rutaceae). Afr. J. Biotechnol. 8(22):6346-6348.

[23]. Mahady, G. B., Pendland, S. L., Yun, G. S., Lu, Z. Z. and Stoia, A. (2003). Ginger (Zingiber officinale Roscoe) and the gingerols inhibit the growth of Cag A+ strains of Helicobacter pylori. Anticancer Research., 23:3699-702.

[24]. Mohammed, S. S. D., Ndalati, A.G., Wartu, J.R., Afangide, C.S. and Aigbogun, E.I. (2017). Mycological Assessments of Postharvest Rot of Irish Potato Tubers from Selected Market within Kaduna Metropolis, Nigeria. Asian Journal of Science and Technology, 08, (06), 4981-4984

[25]. Muhammad, S., Shehu, K. Amusa, N. A. (2004). Survey of the market diseases and aflatoxin contamination of tomato (Lycopersicon esculentum MILL) fruits in Sokoto, northwestern Nigeria, Nutrition and Food Science, 34 (2): 72-76.
[26]. Nwachukwu, E. O. and Osuji, J. O. (2008). Evaluation of plant extracts for antifungal activity against Sclerotium rolfsii causing cocoyam cormel rot in storage. Research Journal of Agricultural and Biological Science, 4(6), 787-793.

[27]. Nwauzoma, A.B., Jaja, E. T. and Njoku, C. (2017). Preventive and curative control of sclerotium rot disease of cocoyam cormel (Colocasia esculenta [L.,Scott]) using plant extracts and Trichoderma koningii. Journal of Applied Biology and Biotechnology, 5(6):40-44. DOI: 10.7324/JABB.2017.50606.

[28]. Okigbo, R. N. and Igwe, D. I. (2007). The antimicrobial effect of Piper guineense "Uziza" and Phyllantus amarus" "ebe benizo' on Candida albican and Streptococcus faecalis. Acta Microbiologica Immunologica Hungarica, 54(4), 353-366

[29]. Okigbo, R. N. and Odurukwe, C. N. (2009). Occurrence and control of fungal rot pathogens of yam (Dioscorea rotundata poir) with leaf extracts of Chromolena odorata, Carica papaya and Aspilia Africana. Nig. J. Mycol., 2(1): 154-165.

[30]. Onuegbu, B. A. Fundamentals of crop protection, Agro-science consult and extension. River State University of Science and Technology, 237-240.

[31]. Onwubiko, O. and Mbanaso, E.N.A. (2005). Millenium Development Goal. In: Asumugha, G. N., Olojede, A. O., Keorgu, J. G., Amo, A. O. Herbert, U. (eds). Repositioning Agriculture for Suitable Millennium Development Goals in Nigeria. Proceedings of the $40^{\text {th }}$ Annual Conference of Agriculture Society of Nigeria held at Umudike, Abia State. pp 368 - 381 .

[32]. Oyewale, M. O. (2006). Fungal diseases of sweet potato. http://acs.Convex.Com/acs/gree06/techprogram/P269 99.HTM

[33]. Salami, A.O, and Popoola, O.O. (2007). Biochemical interactions of mycorrhira and soil-borne microorganism on growth pepper (Capsicum annium (Linn.)) seedlings. Journal of Agricultural Science, 52 (1):17-31.

[34]. Strivastava, D. K. \& Kshma, S. (2014). Antifungal Activity of leaf extract of Neem (Azadirachta Indica Linn), International Journal of Current Microbiology and Applied Science, 3(5), 305-308

[35]. Ubalua, A. O. and Chukwu, L. I. (2008). Potentials and constraints of cocoyam production in Nigeria. Proc. 42nd Ann. Con. Agric. Soc. of Nigeria. Ebonyi State University Abakiliki, pp 298-302.

[36]. Ugonna, C. U., Jolaosa, M. O. and Onwualu, A. P. (2013). A Technical Appraisal of Potato Value Chain in Nigeria. International Research Journal of Agricultural Science and Soil Science 3 (8): 291 301.

[37]. Wee, Y. C. (1992). A guide to medicinal plants. Singapore science centre, pp 33. 